\title{
A MERITOKRÁCIA VÁLLALATOKON BELÜLI MEGVALÓSULÁSÁNAK KÉRDÉSEI EGY KVALITATÍV KUTATÁS TÜKRÉBEN
}

Számos kutató azt várta, hogy a meritokrácia, azaz az érdemek alapján történő érvényesülés elve a vállalatokon belüli fog először megvalósulni a globalizálódó verseny körülményei között. Azt várták, hogy a növekvő hatékonysági követelmények következtében a tehetség és rátermettség szerepe erősödik a nemi és etnikai csoportokhoz tartozás vagy a kapcsolati hálókon belüli pozíció torzító hatásával szemben. Ez azonban sok esetben nem így történt. Ezt mutatja például az egyik statisztikai adatok által jól dokumentált terület, a nők alacsony részvétele a versenyszektor magánvállalatainak felső vezetésében. Ahol a részvételi arány növekedése tapasztalható, ott is olyan struktúrában valósul meg, ami sok esetben politikai célok formális és nem tartalmi teljesítésére utal.

Férfi felső vezetőkkel folytatott interjúk során arra derült fény, hogy a női felsővezetői részvételt annak ellenére konstruálják, értelmezik különbözőképpen a döntéshozók, hogy valamennyien felelősnek érzik magukat cégük hatékony működéséért. Eltérő konstrukcióik jellemzőinek összegzése a hatékonyság és a meritokrácia mentén a görög mitológiából származó metaforák segítségével történik. A kutatás eredményei a háttérben ható tradíciók és tudattalan torzítások miatt a párbeszéd, a meggyőzés és a jó tapasztalatok megosztásának fontosságára hívja fel a figyelmet. A célok internalizálására még a meritokráciát támogató belső szabályok és kvóták mellett nagy szükség van, mert csak így valósulhat meg a vallott és követett értékek egysége. ${ }^{1}$

\section{Kulcsszavak: meritokrácia, leadership, nők a vezetésben, vezetéstudomány, kvalitatív kutatás}

A meritokrácia, azaz az érdemeken alapuló érvényesülés elvének teljesülését és sérüléseit is megfigyelhettem szakmai életutam során. Nemcsak az akadémiai világ kutatójaként, hanem az üzleti világban közép- és felső vezetőként is. A cikk első része a meritokrácia felemás megvalósulását mutatja be egy statisztikailag is mérhető eseten keresztül, majd áttekinti a korábbi kutatások adta magyarázatokat. A második rész egy nagyobb empirikus kutatás meritokráciára fókuszáló részét tárgyalja, mely során nem pusztán kívülálló szemlélőként, hanem a kutatásba bevont szereplök partnereként is reflexív és koherens tudás kialakítása volt a cél. E rész ezért - élve a kvalitatív kutatások színes eszköztárával - két megközelítést is tartalmaz, egy kutatói önreflexiót és egy félig strukturált interjúkon alapuló interpretatív kutatást, ahol metaforák segítik a narratívák interpretációit. Végül pedig, a záró gondolatok keretében a kutatás eredményeinek összefoglalására, a korlátok számbavételére és további kutatási irányok áttekintésére kerül sor.

\section{A meritokrácia és a vállalati hatékonyság}

Amikor Michael Young angol szociológus és politikus szatirikus írásának a „The Rise of the Meritocracy” (1958) címet adta nem sejtette, hogy a szó hamarosan elválik szatirikus tartalmától és egy, már az ókortól létező fogalom megnevezéseként válik közismertté. A meritokrácia eb- ben az értelemben olyan társadalmat, szervezetet jelent, ahol az egyén hatalma, pozíciója és elismerése a képességeitől, képzettségétől és teljesítményétől, azaz érdemeitől függ, tehát nem származás, vagyon, vagy egy előnyben részesített társadalmi csoporthoz való tartozás függvénye.

A Magyarországon e tárgyban végzett korábbi kutatások azt vizsgálták, hogy az egyenlőtlenségek okait a társadalom tagjai hogyan érzékelik. Mennyiben tekintik azt az egyén tehetsége, erőfeszítése és eredményessége következményének, vagy mennyire vélik úgy, hogy azt inkább társadalom intézményei, a hatalmi viszonyok és a kultúra határozzák meg (Kluegel - Csepeli - Kolossy Örkény - Neményi, 1995; Örkény - Székelyi, 2000). Egyik fontos megállapításuk az volt, hogy bár voltak különbségek, de összességében a posztszocialista országok egyre hasonlatosabbakká váltak a fejlett országokhoz, ahol a meritokráciában való hit státuszfüggővé vált - attól függ, hogy milyen az egyének és csoportok társadalmi helyzete és érdekei.

Ezen az elemzések során a kutatók a társadalom egészének attitüdjeit kutatták. Ezzel szemben e cikk a társadalom egy olyan szegmensében, a magánszektor versenykörülmények között müködö vállalatainak körében, kutatja a meritokrácia megvalósulását, ahol a teljesítmény kiemelten fontos. 


\section{Harmónia az elméletben}

A külső megfigyelő számára a versenyszféra magántulajdonú vállalatai esetében a meritokrácia, azaz az érdemelvűség érvényesülése logikus várakozás, hiszen tulajdonosok és befektetők befektetéseik minél gyorsabb megtérülését várják, amit a cégek menedzsmentjének más vállalatokkal éles versenyben kell elérniük. Ez volt a várakozásuk a téma kutatóinak is harminc-negyven évvel ezelőtt (Alvesson - Billing, 1997; Adler, 1986/87; Reif, 1975; Martin, 1993). Gondolatmenetük lényege szerint, mivel az erőforrások lehető leghatékonyabb felhasználása a cél, ebbe beletartozik az emberi eröforrások, azaz például a férfiak és nők, a más-más kultúrákból, társadalmi csoportokból vagy eltérő kapcsolati hálózatokból származó dolgozók tehetségének és teljesítményének megfelelő hasznosítása is. Ez a gondolatmenet más megközelítésekkel szemben nem a társadalmi szintű igazságossági cél megvalósulásának, hanem technokrata módon a hatékonyság, a versenyképesség eszközének tekinti a meritokráciát, ami a vállalatnak, mint egésznek ugyanúgy érdeke, mint tehetséges dolgozóinak egyénenként.

A társadalomtudományok különböző ágai saját elemzési keretein belül foglalkoznak a témával. Az egyszerü mikroökonómiai és növekedési modellek úgy írják le, hogy az azonos hasznosságú munkaerőt homogénnek tételezik, nem különböztetnek meg társadalmi hovatartozás szerinti csoportokat a munkaerő azonos hasznosságú csoportjain belül (Acemoglu, 2009). A leadership elméletek pedig ugyan implicit módon a meritokrácia elveit tekintik irányadónak a vállalatok vezetésében, bár ennek gyakorlati megvalósulására általában nem fordítanak különösebb figyelmet (Broadbridge - Simpson, 2011; Powell, 2012).

\section{Ellentmondás a gyakorlatban}

A meritokráciától való eltérés feltárása, nyomonkövetése és elemzése azokban az esetekben egyszerübb, ahol megbízható adatok jelzik az egyenlötlenségeket vagy aránytalanságokat. A vállalati müködés egyes jellemzőiről gyüjtött statisztikai adatok tükrében például megállapítható, hogy a meritokrácia elve a gyakorlatban több esetben nem teljesül. Az adatok nemcsak egyes eltérések helyeit mutatják meg, de számszerüsítik azok mértékét is. A jelenségek mélyebb okainak kutatásához azonban a figyelmet felhívó kvantitatív elemzésen túl, kvalitatív kutatási módszerek alkalmazása is szükséges. A kutatás korlátját jelenti ugyanakkor, hogy a meritokrácia elveitől való eltéréseket nehezebb bizonyítani olyan területeken, ahol számszerü adatgyüjtés nem történik.

A statisztikailag megfigyelt csoportok egyik példája a nők és a férfiak csoportja. Megbízható adatok állnak rendelkezésre például a társadalmi szintü meritokrácia egyik fontos eleméről az oktatáshoz való nemek szerinti hozzáférésről is. Ebből a szempontból az Európai Unióban inkább a férfiak enyhe hátrányáról beszélhetünk, mert bár nagyok a szakterületi különbségek, összességében a felsőoktatásban tanulók 54,1\%-a nö (Eurostat, 2017).

Ahol a meritokrácia a nők hátrányára sérül, az például az a jelenség, hogy képzettségükhöz mérten aránytalanul alacsony arányban vesznek részt a vállalatok vezetésében. Ez még akkor is igaz, ha figyelembe vesszük, hogy a foglalkoztatottságban a nők elmaradnak a férfiaktól (76\% vs. 64\%). Az elmúlt években meghozott, a nők vezető testületekbe, döntéshozói munkakörökbe való jutását segítő számos határozat (European Comission, 2016a) és megtett intézkedés ellenére (European Comission, 2016b), a női részvétel a valódi információkkal járó, szerepmodellként is funkcionáló „executive”, azaz napi vezetői tevékenységet magába foglaló pozíciókban alig változott (lásd 1. ábra), az európai átlag ugyanis továbbra is csak 15\% (Magyarországon csupán 10\%).

\section{1. ábra Executive igazgatósági tagok aránya nemek szerint (2017 1. félév, \%)}

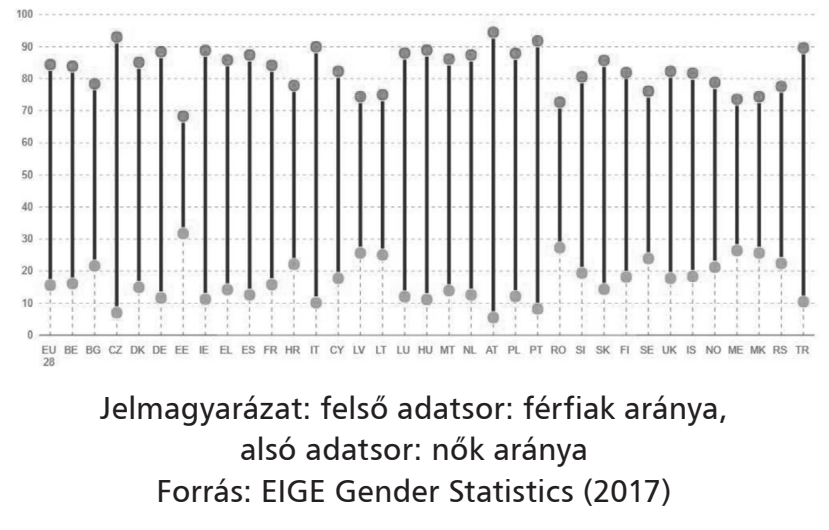

Ahol elmozdulás tapasztalható, az a súlytalanabb, napi vezetői feladatokkal nem járó, ,non-executive” pozíciókban lévő nők aránya, ahol az európai átlag 27\%-ra emelkedett (Magyarországon csupán 15\%) (EIGE, 2017). E tendencia a 35 országból 25-ben megfigyelhető. Kiugróan nagy a különbség Franciaországban, Olaszországban, Izlandon és Norvégiában, ahol erős szabályok ösztönzik a cégeket a női részvétel növelésére.

A kétféle női részvétel közötti látványos eltérés a szabályok és kormányzati ajánlások formális és nem tartalmi teljesítésére utalnak. A non-executive pozícióban lévő igazgatósági tagok ugyanis általában más tevékenységük mellett, részmunkaidőben látják el feladataikat, ritkábban találkoznak egymással és nem jelennek meg a vállalatok hétköznapjaiban (Pass, 2004). Sokkal kevesebb belső információval rendelkeznek, ezért az üzleti döntésekben való érdemi részvételük korlátozott. Nem jelennek meg a dolgozók előtt, nem tudnak szerepmodellként mintát adni a dolgozók számára. A non-executive igazgatósági tagok feladata fontos, de nem belső döntéshozói jellegű. Ốk ugyanis a „külső szem”, ami azonban a nők esetében a többi területen való háttérbe szorultságuk miatt nagyon korlátozottan mutat csak a meritokrácia irányába.

$\mathrm{Az}$ érdemi döntéshozói testületekben tapasztalható alacsony női részvételi arány, a vezetői kinevezések során a nők mellőzésének magyarázatát kísérletek, tanulmányok vizsgálták és vizsgálják, melyeket összefoglalóan tárgyalja Eagly és Carli (2007), Broadbridge és Simpson (2011), valamint Powell (2012). A kvantitatív elemzések sokat elárulnak a jelenségekről, az okok feltárásánál azonban a módszerből adódó korlátaik vannak. 
A pusztán kvantitatív kutatások kockázatait jól jellemzi a világszerte nagy port felvert eset, amikor például a német bankok igazgatótanácsairól az 1994 és 2010 közötti időszakban készült elemzésből elsőre azt a következtetést vonták le a szerzők, hogy az igazgatótanácsban a nők magasabb aránya kockázatosabb üzleti modelleket eredményezett. Mélyebb elemzésre volt szükség ahhoz, hogy világossá váljon, hogy nem a nők arányának növekedése volt a magyarázó tényező, hanem az újabb tagok fiatal korából származó tapasztalatlanságuk, ugyanis az átlagéletkor csökkenése növelte meg a banki portfóliók kockázatát (Berger - Schaeck - Kick, 2013). Bár ebben az esetben a magyarázó tényező még kvantitatív eszközökkel kimutatható volt, de jellege - az életkor, mint döntést befolyásoló tényező - jelzi, hogy számos esetben előfordul, hogy fontos, nagy hatású belső tényezők - mint például a döntéshozatali folyamatok belső dinamikái (Kanter, 1977a, p. 206-242.; 1977b) - nehezen számszerüsíthetők.

A vállalatok vezető testületeiben zajló folyamatok, a döntéshozók véleményalkotásának, döntéseinek háttere kvalitatív kutatási eszközökkel (Mason, 2005; Kvale, 2005; Denzin - Lincoln, 2005; Maxwell, 2013; Horváth Mitev, 2015) ismerhető meg. Egy ponton túl ugyanis már nem a mennyiségek vizsgálata a kérdés, hanem az, hogy a szereplők - esetünkben a túlnyomórészt férfi döntéshozók - hogyan konstruálják önmaguk számára a jelenségeket, és a konstrukciók milyen döntésekben, milyen viselkedésekben és kollektív konstrukciókban öltenek testet.

A szakirodalom áttekintése alapján megállapítható, hogy a magánszektorra fókuszáló kvalitatív kutatások jellemzően női szereplők bevonásával, az ő percepcióik, konstrukciók interpretációjával történt. A női vezetőkkel kapcsolatos kutatások esetén ők, a női vezetők általában szívesen vesznek részt azokban, én magam is többször voltam kutatóinterjúk alanya vállalatvezetőként. Ritkák azonban a férfi döntéshozók bevonásával zajló kutatások (Collinson - Hearn, 1994; Hanappi-Egger, 2011, p. 103113.), ugyanis ebben a kérdésben a férfi döntéshozók a kutatók számára nehezebben megközelíthetők, mint a női vezetők. Korábban ennek okai föleg az érdektelenség és a bizalmatlanság voltak, napjainkban pedig a fejlett országok többségében már a nők számára kedvező társadalmipolitikai elvárások befolyásolják a kérdésről hangoztatott nézeteiket, vélekedéseiket. Magyarországon azonban ilyen elvárások a társadalom oldaláról alig, a politika irányából pedig egyáltalán nem fogalmazódtak meg, ezért nálunk a férfiak bevonásával folyó kutatások eredményeit ilyen tényezők nem befolyásolják.

A mai magyar politikai életet egyértelmüen férfiak uralják: Európában a magyar parlamentben a legalacsonyabb a női képviselők aránya, a kormányban sok éven keresztül nem volt egyetlen női miniszter sem. Ami a nők vállalati felsővezetői részvételét illeti, az EU nemzetközi statisztikai felmérése szerint, a tőzsdén jegyezett blue chip cégek igazgatóságában az egyik legalacsonyabb a nők részvétele Európában (lásd 1. ábra).

Magyarországon ugyanakkor az is elmondható, hogy, mint cseppben a tenger, az országon belül a szervezeti kultúrák nemzetközi sokszínűsége figyelhető meg: a kü- lönböző anyaországból érkező multinacionális cégek aránya az Európai Unióban Írország után a második legmagasabb, árbevétel és hozzáadott érték alapján $50 \%$ feletti, a foglalkoztatottakon belül pedig meghaladja a $25 \%$-ot (KSH, 2016).

A cikk arra a kérdésre keresi a választ, hogy melyek azok a tudatos és tudattalan nézetek, vélemények, vélekedések és hiedelmek, amik a férfi felsővezetői döntéshozók kinevezési döntéseit a meritokrácia elveivel ellentétes módon befolyásolják. Miért történnek olyan döntések, melyek a női tehetségek mellőzésével, ezzel az értékes erőforrások egy részéről lemondva, a hatékonysági potenciál csökkenéséhez vezetnek? Vannak-e kivételek és azoknak milyen jellemzői vannak?

A továbbiakban a kutatási kérdések szempontjából releváns szakirodalom áttekintése után a kvalitatív kutatást és annak eredményeit ismertetem. Ezen belül elöször az általam alkalmazott módszereket, majd a kutatói önreflexiót, a kutatás körülményeit, alanyait, az elemzést és a következtetéseket mutatom be.

\section{Szakirodalmi áttekintés}

Húsz évvel ezelőtt a nők érvényesülési lehetőségeinek javulása szempontjából Alvesson és Billing (1997) Adlerrel (1986/87), Reiffel (1975) és Martinnal (1993) egyetértve, a többi vizsgált területhez képest, a vállalati szektort illetően voltak a legbizakodóbbak. A nők és a management viszonyát tárgyaló sok korábbi kutatást is áttekintő írásukban megkülönböztetett figyelmet szenteltek a meritokrácia kérdésének. Elméleti modelljükben az értékelvüség kérdése a nemek hasonlósága és az üzleti hatékonyság metszéspontjában található, kifejezve azt a véleményüket, hogy az üzleti világban szükséges képességeket tekintve nincs olyan különbség a két nem között, melyek akadályát jelentenék annak, hogy tehetséges képviselöik egyaránt hozzá tudnak járulni a hatékonyság növeléséhez. Úgy vélték, hogy a versenyszféra teljesítménykényszerének hatására a felsővezetői döntéseket meghozó, zömmel férfi vezetők rákényszerülnek arra, hogy tehetséges női munkatársaikat vezetői feladatokkal bízzák meg és befogadják őket a döntéshozó testületekbe is. Ha bíztak is a jövőben, tudóshoz méltóan megfogalmaztak néhány kételyt is.

A cikk megjelenése óta történtek alapján megállapíthatjuk, hogy inkább kételyeik, mint optimizmusuk teljesült. Bár a vezetéstudományi kutatók többé már nem zárják ki kutatási mintáikból a nőket, a jelenlegi leadership elméletek közül sokat férfiakra gondolva fejlesztettek ki (Powell, 2012). A globalizáció nyomán ugyan egyre erőteljesebben jelennek meg a diverzitásnak és ezen belül például a nők bevonásának a hatékonyságra gyakorolt pozitív hatásai, amit értelmezhetünk úgy, mint a meritokrácia kérdéseinek feszegetését, ezeket a témákat azonban elkülönült szekciókban tárgyalják a konferenciákon és többnyire más szaklapok foglalkoznak velük, mint a ,leadership" címkével ellátott kérdésekkel. Az okokat kutató elméleti megközelítések integráltságának hiánya jól tükrözi a gyakorlatban tapasztalható skizofrén helyzetet.

A meritokrácia sérülésének okai a mélyben rejtőznek. A semlegesnek tekintett kritériumok ugyanis, melyek el- 
vileg a meritokrácia alapját adják, gyakran tartalmaznak a férfiak számára kedvező, részrehajló elemeket (Lewis - Simpson, 2010). A meritokrácia eszméje - amely elvileg az iskolázottság, a tapasztalat és a készségek elvileg objektív ismérvein nyugszik - erősen átértelmeződik e fogalmak munkahelyi interpretációi és azok alkalmazásai során (Broadbridge - Simpson, 2011). Az érdemelvűség torzítottsága ellenére sokszor hivatkozott mentség a nők alacsony reprezentációjára a felső vezetésben. A férfi felső vezetők szívesen hivatkoznak a felvételi és előléptetési döntéseiket vezérlő érdemelvüségre, hogy bizonyítsák a nemi egyenlőség melletti elköteleződésüket. Azt azonban ritkán kérdezik meg önmaguktól, hogy mit is tekintenek érdemnek (Simpson - Ross-Smith - Lewis, 2008).

Az ,üvegplafon” metafora (White - Morrison - Van Velsor, 1987; Liff - Ward, 2001; Powell, 2012) az idők során elavulttá vált, mert néhány nőnek sikerült - ha felemás módon is, mint láthattuk - áttörniük az üvegplafont, viszont kiderült, hogy nem csak a legfelső szinteken vannak láthatatlan falak. Az új metafora, a „labirintus", a soha véget nem érő kihívásokat fejezi ki, melyeken a nőknek sorra át kell jutniuk, hogy megszerezzék, megkapják és hatékonyan gyakorolhassák vezetői pozíciójukat a hierarchikus szervezetekben (Eagly - Carli, 2007). Ennek jellemzői például az „üvegfalak” (Eagly - Carli, 2007; Nagy, 2007; Nagy - Primecz, 2010; Zahidi - Ibarra, 2010), melyek észrevétlenül a támogató funkciókba zárják a nőket, ahonnan nem vezet a középvezetőnél feljebb az út, vagy az ,üveglift” (Williams, 1992), ami a zömmel nőket vonzó területeken a kevés férfi gyors elörejutását szimbolizálja.

Sok ország adatait elemző kutatásukban Carter és Silva (2010) azt mutatták meg, hogy a nők kinevezése minden egyes karrierlépcsőnél elmarad a férfiak mögött, még azoknál a vállalatoknál is, ahol célzott programokkal igyekeztek javítani a nők elörejutását. Még a munkatapasztalatok éveinek számával, iparágra és régióra kiigazítva is azt találták, hogy a férfiak a nőknél magasabb szinteken léptek be a cégekhez, magasabb szinten kezdték az előmenetelüket. Ezt az összetett, képlékeny, hátrányos megkülönböztetést fejezi ki a „tűzfal" metaforája, kiemelve a megkülönböztetés folyamatba épített jellegét is (Bendl - Schmidt, 2010).

Alvesson és Billing (1997) szerint mindennek egyik oka a nemek szerinti hagyományos munkamegosztás, ami a nyilvános és a privát terek elkülönülését eredményezte. A nyilvános tereket és az ott működő komplex szervezeteket történelmileg a férfi dominancia jellemezte. A vállalati világot - különösen pedig a legfelső vezetés köreit - egy olyan játékhoz lehet hasonlítani, melyet férfiak találtak ki, férfiak a játékosok, a szabályok pedig a férfiak munkáról alkotott elképzeléseit és elveit követik. Más szerzők is arra a megállapításra jutottak, hogy annak következményeként, hogy a szervezeti kultúrákban gyakran a „férfias" elvek, hiedelmek a meghatározók, az értékek is inkább a sztereotipikus férfiértékekkel állnak összhangban, tehát az erőszakossággal, versenyszellemmel, státuszorientációval, hierarchiával és irányítással (Wajcman, 1998). Történelmileg a legtöbb szervezetet férfiak alapították, és még most is ők uralják, különösképpen a felsőbb vezetést (Terjesen - Singh, 2008).
E folyamat egy másik interpretációja a történelmi férfikutatásból származik, ahol Braudy (2005) arról ír, hogy a piaci viszonyok erösödésével a munka világa távol kerül az otthontól és maszkulin territóriummá vált. A maszkulin identitást a „hivatás” kialakuló eszméjével azonosították, míg a nők továbbra is a család értelmezési keretein belül maradtak (Okin, 1979). Olyan szervezeti kultúrák alakultak ki, melyekben - akarva-akaratlanul - a férfi-preferenciák és életminták adják a normát és a férfi tulajdonságok értéke is magasabb a nőinek tekintett tulajdonságokénál (Meyerson - Fletcher, 2000).

Férfias érdemre az egyik példa az elhivatottság sztereotip definíciója (Schein, 2004). Még a munkát nagymértékben rugalmassá tevő számítógépek, laptopok, internet és okostelefonok korában is az az elterjedt felfogás uralkodik, hogy az elhivatott vezető vállalja, hogy akár késő estig, vagy hétvégén is az irodában van. Mindez különös kihívás elé állítja a nőket, akik hagyományos, család körüli teendőik mellett gyakran képtelenek tartani magukat e normához (Tóth, 2005). Még ha a nő el is tudná fogadni a fenti körülményeket, az ezzel kapcsolatos vélelmek miatt valószínűleg meg sem kérdezik, meg sem kérik rá (Van Oostende - Chiercia - Martens, 2012, p. 12.).

A férfiak jobban hozzáférnek a férfiak kapcsolati hálóihoz, ahová a nagyhatalmú döntéshozók tartoznak - az érdem (merit) e tekintetben sem jelenti ugyanazt a két nem számára. Ez alátámasztja Wajcman (1998) „kortárs patriarchizmus"-elméletét, vagyis a nők alávetését az egyenlőség keretei között. E korlátot legyőzni például mentoráló kapcsolatok kialakításával lehetséges (Allen, 2004), erős pozícióban lévő mentorok képesek a karrierépítést jelentősen megkönnyíteni. Egy magyarországi kutatás (Kürtösi, 2007) egy női vezetésü cégben azt mutatta, hogy a nők kevésbé tulajdonítottak jelentőséget az informális kapcsolatoknak.

A férfikutatások számára is releváns kérdés a maszkulinitás és a vezetés kapcsolata, mely gyakran összefüggést mutat a meritokrácia kérdéseivel is. Rámutatnak arra, hogy a maszkulinitások meghatározása és értelmezése mélyen beágyazódik a legfontosabb társadalmi intézmények - az állam, az oktatás, a vállalatok és a család - létezésébe, eme intézmények történetileg kondicionált voltát is tételezi. Az általuk ,,hegemón maszkulinitás”-nak nevezett jelenség mechanizmusa azt eredményezi, hogy nem a férfiak általában, hanem a férfiak egyes csoportjai képesek belakni a hatalommal és gazdagsággal járó pozíciókat, illetve képesek legitimálni és újra és újra létrehozni az uralmukat létrehozó társadalmi viszonyokat (Carrigan - Connell-Lee, 1985). A ,hegemónia” fogalma egy olyan hatalomgyakorlási forma, amely a nagy közvetítő rendszerek - mint például az oktatás, a tömegkommunikáció és a filmek - által is közvetített „,magától értetődő tudásként" beépül a gondolkodás felszíne alatti észlelésekbe, és észrevétlenül és mélyen beágyazódik a kultúrába.

Maddok és Parkin (1993) a következő metaforákkal jellemezték a vezetés maszkulin jellegének egyes fajtáit: úriemberek klubja, karrierizmus, öltözői kultúra, kaszárnyaudvar, vállalkozó, gender vak és okos macsó. Collinson és Hearn (1994) pedig a következő öt kultúra, illetve 
vezetési stílus meghatározásával ragadták meg a vezetés maszkulinitásának kérdését, amit egyes esetekben nem csupán a nőkhöz, hanem más, vezetésen kívüli férfi csoportokhoz való viszonyban is meghatároztak: paternalizmus, karrierizmus, informalizmus, auriterizmus és a mímelők. Közülük több is hasonlóságot mutat Maddok és Parkin metaforaival. Fontos fogalmak még a témakör tárgyalásánál a ,jóindulatú” és az „ellenséges szexizmus” (Heilman, 2001; Fiske - Cuddy - Glick - Xu, 2002; Eckes, 2002; Kovács - Szabó, 2017). Az első esetben a nőkre, mint szerethető, védelmezésre szoruló lényekre tekintenek, melyek azonban nem kompetensek a vezetés kérdéseiben. A másodikban a nőknek a döntéshozók informális köréből való tudatos kirekesztéséről van szó. Például az „öltözői kultúra” kialakításával vagy pedig autoriter vezetési stílussal, a „,börtönudvar” légkörével zárják ki a nőket formálisan vagy informálisan a vezetésből.

A nők egyértelmüen alárendelő megkülönböztetése jellemzi a Collinson és Hearn által megfigyelt első négy kultúrát, illetve stílust. Az „úriemberek klubja” kultúra óvja és védelmezi a nőket, de csak addig, amíg azok elfogadják a hagyományos női szerepeket. Hasonlít a paternalizmus vezetői stílusához, ahol a vezető férfiakkal vállal közösséget és a nőktől megkülönbözteti magát. A karrierizmus stílusát a kenyérkereső énkép jellemzi, aki úgy véli, hogy egyedül kell eltartania a családját. Hosszú túlórákat vállal, szűk határidőkkel és az otthoniaktól, a nőktől és a családjától a teljes és feltétel nélküli támogatást várja, és ezt vetíti ki a környezetére is. E kultúrák rokonságot mutatnak a ,jóindulatú szexizmus"-sal jellemzett attitüddel.

A következő kultúrák ezzel szemben gyakran a fenti szerzők által feltárt „ellenséges szexizmus”-t testesítik meg. Az „öltözői kultúrá”-t ugyanis, az „,informalizmus”hoz hasonlóan: a férfiak közötti, nőket kirekesztő kapcsolatépítés jellemzi, amely maszkulin jellegü érdeklődés és értékek alapján szerveződik és ahol a közös témák a sport, a szex, az autók, az alkohol és esetenként a közös alkoholizálás. Szélsőséges formákban mindez szexuális zaklatásig és a nők szexuális tárggyá történő lealacsonyításáig is vezethet. A következő csoportba a „,kaszárnyaudvar” kultúrák tartoznak, melyek a megfélemlítésre építenek, ahol az autoritarizmus a jellemző, mely ellenséges a nőkkel és minden férfival, akit erőtlennek talál, eszköze e csoportok „gyengeség” címkéjü stigmatizálása.

A kevésbé explicit megkülönböztetési módok közé tartozik a vállalkozó (Sinclair, 2005), aki: csak azokat a nőket ismeri el, akik a kenyérkereső férfi szerepének megfelelö viselkedést tanúsítanak. A várandósság és az otthoni kötelezettségek tabutémáknak számítanak. Ehhez hasonló a gender vak, mely álláspont szerint „,mindenki fehér férfi”, valamint az okos macsó, aki hasonló az előzőhöz, azonban annál még versengőbb és szűkebb látókörü. E felfogások egyrészt nem vesznek tudomást a diverzitásról, másrészt nagyon megnehezítik a helytállást a hagyományos családokban élő nők számára. Ök építik az olyan kultúrákat, ahol például késő estig tartó gyakran látszatmunka miatt van mindenki az irodában. Jellemző jegy még a viselkedési normaként elvárt folyamatos agresszivitás is. A kettős kötés - az egymásnak ellentmondó normáknak való meg- felelési kényszer - akár vezetői, akár müszaki funkciókról is van szó - sok bizonytalanságot és szorongást okoz, szélsőséges esetekben kiégéshez, pályaelhagyáshoz vezethet (Hanappi - Egger, 2011).

Végül elérkeztünk a „mímelök”-höz, akik szavakban mindig támogatják a nőket, de soha nem léptetik öket elö, támogató szabályzatokat gyártanak, de sohasem alkalmazzák azokat. Ez a vezetési kultúra felidézi az előző fejezet ellentmondásos adatait a nők részvételéről a különböző igazgatóságokban.

A női felsővezetői részvétellel kapcsolatos, a meritokrácia kérdéskörén túli, további cikkek (Dunavölgyi, 2016) bővebb betekintést nyújtanak a kérdéskör más megközelítésű kutatásaiba - különleges hozzájárulás, alternatív értékek és egyenlő esélyek - melyek bemutatására e cikk keretei között terjedelmi korlátok miatt nincs lehetőség.

\section{A kvalitatív kutatás}

A kutatás célja annak felderítése volt, hogy mi az oka azoknak a döntéseknek, melyek a női tehetségek mellőzésével, az erőforrások egy részéröl lemondva a hatékonysági potenciál csökkenéséhez vezetnek? Melyek azok a tudatos és tudattalan nézetek, vélemények, vélekedések és hiedelmek, amik a férfi felsővezetői döntéshozók kinevezési döntéseit a meritokrácia elveivel ellentétes módon befolyásolják? Vannak-e kivételek? Mik a jellemzőik?

Az e kérdések megválaszolása érdekében végzett kutatás a kvalitatív kutatás metaforái közül a patchwork metaforához (Denzin - Lincoln, 2005, p. 4.) áll legközelebb. A meritokrácia sérüléseinek okait kutató vizsgálatok és azok korlátainak ismeretében úgy véltem, hogy azzal tudok a legjobban hozzájárulni a kérdés kutatásához, ha vállalatvezetői feladataim ellátása közben szerzett tapasztalataim és a munka során kialakult kapcsolatrendszer adta kedvező lehetőségek keretei között próbálom feltárni a jelenség okait. Elemzésem során összefüztem, összekötöttem a kutatás különböző elemeit, az interjúk módszereit, a hallottak interpretációit, metaforáit, valamint saját önreflexióimat is.

A kvalitatív kutatás két részből áll. Az első részben a kutatói önreflexió és az előfeltevések megfogalmazása történik, amit a férfi döntéshozókkal történt interjúk, azok interpretatív elemzése és az előfeltevésekkel történő öszszevetése követ.

\section{A kutatói önreflexió és az előfeltevések}

A kvalitatív kutatás módszertanával foglalkozó szakirodalomban több szerző is hangsúlyozza, hogy számos előny származik abból, hogy egy kutató saját élettapasztalattal is rendelkezik azon a területen, ahol kutatást végez (Mills, 1959; Strauss - Corbin, 1990; Putnam, 1990; Glense - Peshkin, 1992; Maxwell, 2013). Segít a kutatásban, ha a kutató rendelkezik „terepismerettel”, kapcsolatai révén elérhetők számára a szereplők, és ha a tapasztalatai alapján kialakulnak benne előfeltevések és értelmezések is.

Ugyanakkor a kutatás tervezésénél Maxwell (2013) arra is felhívja a figyelmet, hogy a kutató is egy szubjektum és a kutatás eredménye az ö értelmezése, az ő egyéniségén keresztül szűrődik át a megismerés és megértés fo- 
lyama. Egyéni előélete, elméleti felkészültsége, empátiája és a téma iránti érdeklődése, fogékonysága mind egyedi tényező. Törekednie kell arra, hogy ezek ne okozzanak csőlátást vagy vakságot. A kutató akkor jár el helyesen, ha feltárja azt a hátteret, amelyben valóságkonstrukciói kialakultak és megértései gyökereznek. Önreflexióval értheti meg és tudatosíthatja saját hatását. Gould (1995) szerint figyelni kell arra is, hogy a tapasztalat vezesse az interpretációt.

A fentiek ajánlásokat követve a kutatási kérdésre vonatkozó saját tapasztalásaimat és az ezek nyomán kialakult, a szakirodalommal ütköztetett elöfeltevéseket foglalom össze a következökben. Ellis, Adams és Bochner (2010) módszertanának megfelelően ezeket az elemzési keretbe ágyazottan, a tudomány által már korábban feltárt összefüggések tükrében teszem. Annak érdekében, hogy a saját előfeltevéseim transzparenssé váljanak, a kutatás során az első interjút velem készítette egy munkatársam, ami segített e rész elkészítésében.

Szakmai életutam folyamán különböző nemzetközi és magyar szervezetekben dolgoztam felső vezetőként a pénzügyi és a tanácsadó szektorban. A meritokrácia elvei és a hétköznapok gyakorlata közötti eltéréseket korábbi munkahelyeimen is tapasztaltam, az ellentmondás azonban teljes valóságában a Budapesti Értéktőzsde vezetőjeként bontakozott ki számomra. A tökepiacok egyik központi kategóriája, a részvényesi érték, melynek növelése a management feladata a forrásokért folyó, befektetési piaci verseny körülményei között. Némileg leegyszerüsítve azt mondhatjuk, hogy amelyik cégben nem térülnek meg kellö gyorsasággal a befektetések, onnan elmennek a befektetők, annak esik az árfolyama és csőd vagy felvásárlás vár rá. Ezek egyik kimenete sem kedvez a menedzserek további karrierjének. Elemi érdeküknek tűnik tehát e helyzetek elkerülése érdekében a leghatékonyabb megoldások keresése, melynek egyik útja a meritokrácia megvalósulása.

Ugyanakkor számos területen megfigyelhettem a meritokrácia elveinek sérüléseit. Saját észleléseim összhangban vannak a maszkulinitás kutatóinak azon megállapításaival (Carrigan - Connell - Lee, 1985), hogy domináns férficsoportok nemcsak a nőket, hanem a kívülállónak tekintett férfiakat is megfosztják az egyenlő esélyektől. Nemzetközi környezetben ez sokszor például a nemzeti hovatartozáshoz kötődött. Láttam példákat arra is, hogy a domináns csoportok önmeghatározása a közös múlt alapján történt, például cégek összeolvadáskor. A szervezeti navigációban rutint szerzett munkatársaim többek közt a „Ki kinek az embere?”, „Ki hozta ide?” kérdések mentén térképezték fel a lojalitási láncok tagjait. Láttam hazai és nemzetközi példát arra is, amikor a másokat kiszorító „méhkirálynő” (Mavin, 2008) módon viselkedő női vezetők akadályozták meg, hogy más tehetséges nők megfelelö feladatokat és elismerést kapjanak.

Női vezetőként számos személyes tapasztalatot gyüjtöttem a meritokrácia nemek közötti érvényesülése területén is. Saját tapasztalataim önreflexív feldolgozásában sokat segített a szakirodalom női vezetői életpályákkal foglalkozó része. A női vezetők életútjait elemző kutatá- sok tanulmányozása során ,aha” élményeim az üzleti élet történéseihez kötődnek, az ott történtek kapcsán döbbentem utólag rá arra, hogy amit én egyedi tapasztalatként értelmeztem, az több esetben jellemző mintázat.

A szakirodalom az ,üvegszikla” metaforával jellemzi (Haslam - Ryan, 2008; Bruckmüller - Branscombe, 2010) azt a női karrierek estén gyakran megfigyelhető szituációt, ahogy először és azt követően több alkalommal is vezérigazgatói (esetenként más megnevezésü, de hasonló tartalmú) megbízást kaptam. A metafora arra utal, hogy a kinevezés (a sziklára emelés) kockázatos helyzetekben történik, amikor a tehetséges férfi vezetők - több lehetőséggel rendelkezve - nem tolakodnak az állásért és ez megnyitja az esélyt a női jelöltek előtt. Az én eseteimben ezek a vállalatok nagy technológiai változáson mentek át, nagy kihívást jelentő projektbe kezdtek, átszervezték őket vagy új céget alapítottak. Ezek a helyzetek nehéz feladatok megoldását igényelték, mert új stratégiát kellett kialakítani, csapatot, kultúrát építeni és gyors döntéseket kellett hozni. Bár észleltem, hogy a vállalati és üzleti kultúrákban sokszor a konfliktuskeresés volt a jellemző, én az esetek többségében együttmüködésre törekedtem, mégha ez sok kommunikációt igényelt is. A befektetett energia általában megtérült, mert felgyorsította az elfogadási folyamatot a sok - zömében férfi - felső vezető között.

A kutatás érzelmi háttere szempontjából fontos, hogy úgy éreztem, hogy a vezetői világban megtaláltam a helyem, befogadtak, bennem sem alakult ki frusztráció vagy sértettség. A szakirodalom által feldolgozott esetek (Katila - Meriläinen, 1999; Miller, 2002; Featherstone, 2004) többségével ellentétben az informális kapcsolatrendszerből sem éreztem kirekesztve magam. Ehhez férjem együttmüködésére is szükség volt, aki nemcsak a gyereknevelésben, de a társasági és szabadidős programokban is részt vett, mégha időnként idegen is volt számára a környezet.

Csupán egyszer fordult elő, hogy olyan szervezetben dolgoztam, ahol a paternalista, és esetenként még a „ellenséges szexizmus"-sal (Kovács - Szabó, 2017) is találkoztam néhány vezetőtársam részéről. Az esetek döntő többségére azonban nem ez, hanem az együttmüködés, a kölcsönös elismerés és befogadás volt a jellemző.

A gyors beilleszkedést bizonyára megkönnyítette, hogy - a szakirodalom tükrében - nagyon szerencsés voltam abban, hogy a családi és az iskolai szocializációs környezetben sok megerösítést és felkészítést kaptam. E tényezők közé tartozik a korán elhunyt, de vezetői példát mutató édesapám (Nagy, 2001) és számos tanárom bíztatása még olyan területeken is, amik „fiús” dolognak számítanak, mint például a matematika és az informatika iránti érdeklődés (Gill - Sharp - Mills - Franzway, 2008; Barnard - Hassan - Bagilhole, 2012; Szekeres - Takács Vicsek, 2013). E tényezők és az értelmiségi családi háttér, a közgazdász végzettség, a nemzetközi munkatapasztalat és a jó angoltudás szempontjából sem számítottam kisebbségnek. Női mivoltom tett egy 10\%-os kisebbség tagjává a felsővezetői világban.

Tisztában voltam azzal, hogy a nőkben nehezebben bíznak meg a férfi döntéshozók, ezért tehetséges nők esetén szívesen szolgáltam referenciaként is, mert saját tapasz- 
talataim a vegyes összetételü csapatok előnyeiről győztek meg, a könyveléstől az informatikán át a vezetésig. Mégis gyakran voltam egyedüli női résztvevő igazgatósági üléseken. Eközben sokszor hallottam a férfi vezetöket nőkről beszélni. Nem mindig az elismerés és elfogadás hangján. A férfi középvezetők a női vezetötársaikra többnyire a „férfivilágba látogató utazók”-ként tekintettek (Gherardi, 1996), többnyire versenytársat látva bennük. A felső vezetők esetében ilyet már nem tapasztaltam, azonban bár voltak olyan tehetséges nők a környezetünkben, akik meg tudtak volna oldani vezetöi feladatokat is - általában mégsem őket választották. Indoklásként sokféle ok hangzott el, például hogy a nők inkább a végrehajtásban erősek és nem a stratégiában, nincs elég gyakorlatuk, vagy nem elég rámenősek. Ezek az indoklások nagy részét a szakirodalom is tárgyalja (Broadbridge - Simpson, 2011; Powell, 2012; Danowitz - Hanappi-Egger - Mensi-Klarbach, 2012; Kornau - Festing, 2013). Voltak olyan megjegyzések is, amikkel az irodalomban kevésbé találkoztam. Erre példa a feleségekre történő gyakori hivatkozás az indoklások során, vagy az a vélelmezés, hogy a női vezetők mindig rossz viszonyban vannak egymással.

Mindezek a szituációkhoz kötődő, egyediségükben megjelenő beszélgetések ébresztették fel bennem a szándékot, hogy egyszer strukturáltabb módon, tudományos igénnyel foglalkozzak azzal a kérdéssel, hogyan is vélekednek a férfi döntéshozók a nők és a vezetés viszonyáról és a női vezetőkről. Kutatóként pedig nagyon fontos számomra a gyakorlat szempontjából releváns eredmény.

A szakirodalom és saját tapasztalataim alapján előfeltevéseim a következők voltak:

- Feltételeztem, hogy azért kevés a férfi felső vezetők bevonásával történő kutatás, mert nem szívesen vesznek részt benne. Valószínűleg elfoglaltak, nem érdekli őket eléggé ez a téma vagy talán kényelmetlennek találják, úgyhogy eröfeszítéseket kell tennem a meggyőzésükre.

- Az erősen maszkulin társadalmi, politikai környezetben, a statisztikai adatok és személyes élmények alapján erősen maszkulin narratívákra is számítottam.

- A harmadik előfeltevés abból a nemzetközi tapasztalatból indult ki, hogy a nagyrészt férfiak által végzett kiválasztási és kinevezési folyamatban olyan tudattalan szürők működnek, melyek hátrányos helyzetbe hozzák a nőket. A kérdés az, „itt és most” okairól és az ehhez kötődő konstruálásokról szólt, az ezekre vonatkozó hiányos ismeretek miatt.

A kutatás nem mindegyik előfeltevésemet igazolta.

\section{Kutatás férfi döntéshozók bevonásával}

Bár bőséges szakirodalom tárgyalja a meritokrácia vállalatokon belüli sérüléseinek kérdést, saját kutatásom induktív és feltáró jellegű volt, mert férfi döntéshozók bevonásával történő kutatásra viszonylag ritkán kerül sor. Ezért a korábbi kutatásokon alapuló elméleti tudás befolyásoló hatását - azaz, hogy csak azt lássam, amit az elmé- letek látni engednek - azzal csökkentettem, hogy Suddaby tanácsát követve „középutat kerestem” (2006, p. 635.) és nem ragaszkodtam mereven a már áttekintett elméletek egyikéhez sem.

A kutatás alanyait tehát egy nehezen megközelíthető csoportból, a felsővezetői kinevezési döntéseket meghozó túlnyomórészt férfiakból álló körből választottam ki. Az ő meritokráciával, ezen belül pedig női felső vezetőkkel és a felsővezetői kinevezésekkel kapcsolatos konstrukcióikat, azaz tudatosult és tudattalan nézeteiket, vélelmeiket igyekeztem megismerni és interpretálni. A kutatásba bevonni tervezett csoport tagjai elfoglalt, nagy felelösséggel járó munkát végző vezetők voltak, akik sem nyilvánosan, sem írásos formában nem szoktak megnyilatkozni a kutatott kérdéssel kapcsolatban. Mindez jelentős korlátot jelentett a választható módszerek szempontjából. A kérdőíves felmérés lehetőségét a módszer ismert korlátai miatt vetettem el: a vizsgált téma bonyolultsága, a kinevezési döntéseket befolyásoló tényezők összetettsége és a módszer személytelensége miatt nem volt célravezető alkalmazása. A körülményeket és lehetőségeket figyelembe véve, a kvalitatív kutatás ezen szakaszának módszeréül a félig strukturált interjút választottam.

A mintavétel során a kutatás jellegéhez illeszkedő mintát építettem fel Kvale (2005, 1996), Mason (2005), Gelei (2006), Blaikie (2007) és Maxwell (2013) útmutatásai alapján, melynek megfelelően sokszínű, a vizsgált jelenség sok aspektusát megjelenítő minta kialakítására törekedtem. E fázisban sokat segített az a tény, hogy annak az üzleti-vállalati kultúrának voltam része én is, ahonnan az interjúalanyokat kiválasztottam, személyesen ismertem őket és rendelkeztem egy előzetes képpel azzal kapcsolatban, hogy milyen konstrukciókkal rendelkezhetnek a női vezetőkkel kapcsolatban. Ezt a fázist a „Rendező” metafora írja a legjobban. Ismerve a szereplőket egy hoszszú listát állítottam össze arra számítva, hogy sokan nem vállalkoznak majd a beszélgetésre.

Az első meglepetés akkor ért, amikor mindenki egyből igent mondott. Ezzel a ténnyel az első előfeltevésem mindjárt az indulásnál nem teljesült. A kutatás során tizenkilenc interjúalanyig bővítettem a kört, amikor telítettnek tekinthettem a mintát, mert az utolsó néhány esetben már csak kevés új információ hangzott el. Interjúalanyaim valamennyien a saját ágazatukban a legnagyobbak közé számító cégek - köztük a legnagyobb magyar vállalatok és nemzetközi cégek magyarországi vállalatának - vezérigazgatói, igazgatósági tagjai vagy elnökei, a felsővezetői kinevezésekben részt vevő döntéshozók voltak.

Előzetes ismereteimre és tapasztalataimra támaszkodva, a vizsgált téma szempontjából sokszínűségre törekedtem, ami a vezetési stílusok és a vállalati kultúrák sokféleségét is maga után vonta. Nemzeti hovatartozás szerint magyarok és külföldiek is szerepeltek a mintában. A nemzetközi cégek anyavállalatai központjainak helyszínei között megtalálható az Amerikai Egyesült Államok, Ausztria, Hollandia, Németország, Skandinávia és Magyarország is. Életkoruk alapján szerepeltek a mintában a Howe és Strauss (1992) szerzőpáros által bevezetett megnevezések szerinti Baby boomer-nek nevezett, nálunk 
inkább a Ratkó-korszak gyermekeinek nevezett generáció, illetve az őket követő X-generáció tagjai. Bár nem szerepelt a célok között, de végül ágazati szempontból is sokszínű lett a csoport, sokféle iparág képviselői megtalálhatók benne. Valamennyien felsőfokú végzettséggel rendelkeznek és döntő többségük házasságban, családban élt az interjúk idején.

Már a felkéréskor tájékoztattam az interjúalanyokat a kutatás céljáról, menetéröl és a velük készített interjúk bizalmas, őket egyénileg nem felfedő felhasználásáról (informed consent elv). Az interjúkra 2015 és 2017 között került sor. A ,terepen”, azaz a felsővezetői világban töltött időszak során kialakult kapcsolatrendszer lehetővé tette, hogy „közeli, bizalmon alapuló, egyenrangú” kapcsolatban (Horváth - Mitev, 2015, p. 35.) legyek az interjúalanyokkal. Az interjúk barátságos, nyitott légkörben zajlottak. Egy órásra terveztem a találkozókat, de nagyrészt 1,5-2 órát tartottak, mert az interjúalanyok várakozásomat felülmúlóan nyitottak voltak a témával kapcsolatban.

Megosztották pozitív tapasztalataikat és véleményeiket, de nyíltan beszéltek rossz élményeikről, előítéleteikről is, nemegyszer őszintén keresve önmagukban is annak okait. Néhány interjúalany önreflexíven tárta fel gondolatait, véleményét a feltett kérdésekkel kapcsolatban.

Az interjúk során hatottak rám az interjúk alanyai és én is hatottam rájuk, az ,ihletett kritika" állapotát tapasztalhattuk meg (Rorty, 1992). Utólag többen felhívtak és tovább beszélgettünk, egy interjúalany pedig miután egy látványosan pozitív döntést hozott, azt mondta, hogy az interjú segített neki „rendbe tenni” a gondolatait. Nemegyszer közösen átélt eseményekről, mindkettőnk számára ismert esetekről beszélgettünk, amiket könnyen kontextusba tudtam helyezni és értelmezni. Mindezeken túl, a vezetői világ saját tapasztalatokon is alapuló ismerete, és számos esetben a közös múlt segített az elhangzott információk validálásában. Ezzel az interjúalanyok is tisztában voltak, talán ezért sem észleltem megtévesztési vagy a valóság szépítésére irányuló szándékot.

Ebben a fázisban kutatásom a koreográfus metaforához (Janesick, 2003) állt közel. A gondos tervezés után, mely a menüett rögzített mozgásaihoz hasonlatos, következett az interjúk szakasza sok meglepetéssel, ami improvizációra késztetett. Az interjúkat diktafonnal rögzítettem. Megfogadva Kvale tanácsát (2005, p. 166.), az átiratok miatti információvesztés elkerülése érdekében, a feldolgozás során egy erre alkalmas szoftver segítségével az eredeti hanganyagokkal dolgoztam, melyek egyes motívumait kódolással csoportokba is rendeztem. Az elemzés egymásra épülő hermeneutikai körök mentén történt (lásd 2. ábra). „A megértés állandóan az egésztől a rész felé és vissza az egész felé halad"'- írja Gadamer (2003, p. 207.) a régi nyelvek elsajátításának példáján keresztül magyarázva a folyamatot. A kutatás folyama koncentrikus körökböl áll, egy-egy megértési körrel gazdagodva. A megértés kritériuma, hogy a részek összhangban vannak-e az egésszel.
A 2. ábra az interpretatív folyamat képszerű metaforája. Első körben az interjúk elemzése a közös témákat, motívumait kereső, organikus módon kialakuló kódok segítségével interjúkon átívelő módon zajlott. Ezt követte az interpretatív elemzés, melynek módszerei a kontextusba helyezés, az összehasonlítás, majd pedig távolabbról, kritikus vizsgálat voltak, melyek segítettek feltárni a közvetlen és közvetett jelentéseket. A második lépcsőben történt az egyes interjúk narratíváinak elemzése a fenti eljárás szerint. E folyamatok nem merev lineáris rendben történtek, hanem sokszor párhuzamosan vagy elöre-hátra ugorva. A következtetések kialakulása is folyamatosan történt. Mindezek eredményeként jutottam el az alábbi, átfogó következtetések levonásához.

\section{2. ábra A hermeneutikai kör általános logikája}

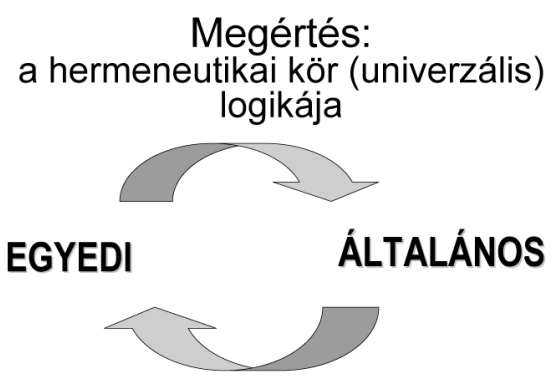

Forrás: (Gelei, 2006, old.: 24.)

\section{Az interjúk elemzése}

Az interjúk során - míg külföldi származású vezetők említették - nagyon ritkán hangzott el magyar származású vezetőtől olyan vélemény, hogy a gyerekes nőknek otthon lenne a helye és a gyereknevelésnek teljes munkaidős elfoglaltságnak kellene lennie. Pedig tisztában voltam azzal, hogy ebben a körben több olyan feleség is van, aki nem vállalt otthonán kívüli munkát és a családjának szenteli az idejét. Ez rávilágított arra a társadalmi kontextus szempontjából fontos tényezőre, hogy a Magyarországon felnőtt interjúalanyok gyerekkorában, az államszocializmus idején a teljes foglalkoztatottság nevében minden nőnek dolgoznia kellett. Magyarországon a 70-es, 80-as években a női foglalkoztatás egyes korosztályokban a 90\%-ot is meghaladta (Pongrácz, 2001). Emiatt az a tény, hogy a gyermekes édesanyák dolgoznak, nálunk kevésbé szokatlan, mint például Nyugat-Európában. Nők azonban az államszocializmus idején sem kerültek nagy számban a politikai vagy vállalati felső vezetésbe.

Közös tulajdonságként valamennyi interjúalanyról elmondható, hogy tevékenységük során mélyen átérzik saját kiemelt felelősségüket abban, hogy az általuk vezetett cég hatékonyan müködjön, és a részvényesi érték fenntarthatóan növekedjen. Egyes esetekben ezt kiegészítette olyan narratíva is, ami a társadalom egészének jövőéért érzett felelősséget is hangsúlyozta. Abban azonban már sokkal nagyobb eltérések voltak, hogy a nők felsővezetői részvétel meritokratikus és hatékonysági aspektusait hogyan értelmezték a megkérdezett vezetők. 
3. ábra A férfi döntéshozók narratívái a nők felsővezetői részvételéről

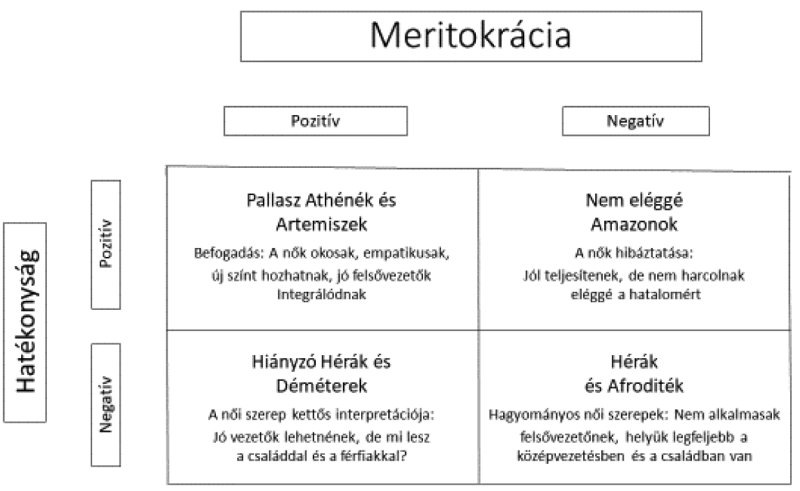

A 3. ábra a cikk alapkérdései által meghatározott két dimenzió - meritokrácia és hatékonyság - mentén foglalja össze a jellemző narratívákat. A női archetípusok bemutatásához Bolen (2008) az ókori mitológia istennőihez fordult. A férfivezetőkkel folytatott interjúk során folyamatosan kibontakozó nőkről alkotott képeket és a jellemző narratívák metaforáit én is a görög mitológiában találtam meg. Bolen könyvén túl Trencsényi-Waldapfel (1983, 1990), valamint Graves (1981) voltak az iránymutatók, a metaforák pedig a mitológiai alakok alábbiakban kiemelt tulajdonságain alapulnak (lásd 4. ábra).

4. ábra A görög istennők és mitológiai lények nevei és a metaforákban megidézett főbb tulajdonságai

\begin{tabular}{|l|l|}
\hline $\begin{array}{l}\text { Istennők és mitológiai } \\
\text { lények }\end{array}$ & Főbb tulajdonságok \\
\hline Pallasz Athéné & $\begin{array}{l}\text { a bölcsesség, a tudományok, } \\
\text { a bátorság és a mesterségek } \\
\text { istennője }\end{array}$ \\
\hline Artemisz & $\begin{array}{l}\text { a vadászat istennője, } \\
\text { versengő, céltudatos és } \\
\text { autonóm, } \\
\text { de védi a gyengébbeket }\end{array}$ \\
\hline Héra & $\begin{array}{l}\text { a családi tüzhely őrzője, } \\
\text { Zeusz főisten felesége }\end{array}$ \\
\hline Déméter & az odaadó anya \\
\hline Afrodité & $\begin{array}{l}\text { a szerelem és szépség } \\
\text { istennője }\end{array}$ \\
\hline Amazonok & $\begin{array}{l}\text { a mondák harcias } \\
\text { asszonynépe }\end{array}$ \\
\hline
\end{tabular}

Felhasznált források: Graves (1981),

Trencsényi-Waldapfel (1983, 1990) és Bolen (2008)

\section{Pallasz Athénék és Artemiszek}

A mindkét dimenzió mentén pozitív narratívák arról szólnak, hogy a női felső vezetőket integrálódott partnernek tekintik, a meritokrácia jegyében elismerik erényeiket és úgy vélik, hogy vezetői tevékenységükkel hozzájárulnak a vállalati hatékonyság növekedéséhez. E vezetők véleménye szerint a női felső vezetők megközelítései és érvei színesítik a gondolkodást, szélesítik a döntési horizontot és sem stratégiai, sem hétközna- pi kérdésekben nem tévesztik szem elöl a szervezetek misszióját. Úgy vélik, hogy a női felső vezetők bölcsessége, béketeremtő képessége és empátiája erősíti a szervezeti kultúrát. E narratívák metaforái Pallasz Athéné bölcsessége és a stratégia tehetsége miatt és Artemisz, aki céltudatos, autonóm és empatikus nő, aki védi a gyengébbeket.

Az egyik jellemző narratíva a diverzitás előnyeiről szólt:

„Ha egy nö ugyanazt az egyetemet végzi és ugyanazt a mantrát hallgatja bizonyos dolgokat ösztönösen másként fog megközelíteni és ez nagyon jó [...] a diverzitás más forrásait szerintem az emberek túlbecsülik."

Egy rendkívül teljesítményorientált vezető az alábbi történelmi érvet hozta fel a nők vezetői képességeik bizonyítására:

„Ha megnézzük a férfi és női uralkodókat, akkor azt látjuk, hogy bár a nök kevesebben voltak, mint a férfiak, de arányaiban a nöi uralkodók között sokkal több volt a sikeres, mint a férfiak között."

A monokulturálisan csak férfiakból álló vezető testületekkel kapcsolatban többen megfogalmazták, hogy könnyen válnak öncélú háborúskodások, kakasviadalok színterévé, melynek egy példája a következő:

„Én azt mindig jobbnak tartom, ha van bent nö, [...] rákényszerit arra, hogy igazgatóságként [müködjön], nincsenek kiszólások.”

A női empátia is többször szerepelt a főleg nők által képviselt pozitív attitüdök között, ami nem engedi szem elöl téveszteni a vállalat misszióját és a dolgozókat sohasem számoknak, hanem embereknek tekinti.

\section{Nem eléggé Amazonok}

A 3. ábra jobb felső sarkába tartozó narratívák a hatékonyság szempontjából előnyösnek ítélik a nők felsővezetői részvételét, azonban saját meritokrácia értelmezésük szerint a nők nem tesznek meg mindent, hogy felső vezetővé válhassanak. Ennek egyik gyakran említett példája, hogy a nők nem harcolnak eléggé a hatalomért. A metafora azért a „Nem eléggé Amazonok”, mert ebben a megközelítésben a tehetség nem elég, az amazonok harciasságát várják el a nőktől a döntéshozó férfiak.

E vélekedések összhangban van azokkal a korábbi kutatási eredményekkel, amik a férfias, „macsó” hagyományok szerint értelmezik a meritokráciát és az ehhez való igazodást várják el a nőktől (Maddock - Parkin, 1993; Alvesson - Billing, 1997; Wajcman, 1998; Terjesen - Singh, 2008). Erről így beszélt az egyik interjúalany a foci világából hozott példa segítségével:

„Lehet, hogy a fiúk mindig gólt akarnak rúgni és csatárok lenni a focimeccsen és a nök szeretnek kapusok is lenni. Könnyebben el is fogadják, lehet, hogy nem akarnak annyira gólt rúgni." 
Egy másik interjúalany az alábbi példával támasztotta alá véleményét:

„A férfi nemi szerepe az, hogy minél több utódot nemzzen, és ezért versenyezzen a másik férfival. [...] Az egymással való kakaskodásnak fontos evolúciós elönye van."

A nők nem eléggé maszkulin, agresszív viselkedése tehát az egyik ok az ebbe a csoportba tartozó narratívák szerint. E vélemények felemásságát mutatja, hogy ha egy nő céltudatos, akkor gyakran éri a vád, hogy „túl agresszív”, „férfivá vált” és már nem is nő többé (Gherardi, 1996):

„, azt vettem észre, hogy egyszerüen férfivá akar válni. Müvi módon, tehát nem önmagát adja, hanem úgy próbál viselkedni, ahogy egy férfivezetö viselkedik."

Ez a megjegyzés hasonlatos Gherardy „A kígyó a füben" (1996, p. 191.) metaforájához, amivel az olyan eseteket jellemzett, ahol a kinevezö férfivezetők belső ellenségként kezdenek tekinteni a vezető pozícióba kinevezett nőre, amikor az elkezdi átlátni a viszonyokat és változásokat szeretne végrehajtani, például nagyobb transzparenciát szeretne teremteni a szervezetben, ami a kinevezőknek nem tetszik. Példája ugyanakkor annak is, hogy a szerethetőség és a kompetencia összeegyeztethetetlenek sok férfi számára (Kovács - Szabó, 2017).

A táblázat alsó két négyzetében található, a hatékonyság szempontjából negatívnak ítélt női felsővezetői részvétel ugyanazon tőről, a hagyományos női szerepfelfogásból fakad. A narratívák egyik csoportja azonban a meritokrácia szempontjából pozitívnak, jogosnak tekinti a nők bevonását, míg a másiknak erröl negatív a véleménye.

\section{Hiányzó Hérák és Déméterek}

A bal alsó negyed narratívái elismerik mind a női tehetséget, mind a hozzáadott értéket a vállalat teljesítményéhez, ha a cégkultúra erre kötelezi öket, elö is léptetik a tehetséges nőket felső vezetővé. Mindeközben azonban úgy vélik, hogy ez valami módon természet- vagy társadalomellenes. Aggodalmuk a tradicionális férfiasságok körüli morális pánik diskurzusokhoz hasonlóan (Acker, 1995) az, hogy mi lesz az emberiséggel, ha a hagyományos női szerepeket már nem látják el a nők? A metafora a „Hiányzó Hérák, Déméterek”, mert Héra, Zeusz felesége, a családi tűzhely őrzője, aki a közösség jövőéért is felelős, míg Déméter az odaadó anya, az anyák őstípusa.

A következő narratíva a férfiak miatt aggódik az alábbiakban:

„Szép, hogy vezetők lesznek a nök, de ki szüli majd a gyerekeket? És csak csendben kérdezem, mit tesz ez a férfiak férfiasságával?"

Egy másik narratíva a feleségek és férjek viszonyát elemzi:

„Az én élettapasztalatom szerint a nök szeretnek felnézni a férjükre. Ebben az új világban ez hogyan lehetséges? Jót teszünk ezzel?"
E kontrukciók egy része rokonságot mutat az „úriemberek klubja" (Maddock - Parkin, 1993) kultúrával és a paternalizmus (Collinson - Hearn, 1994) vezetői stílusával, valamint a ,jóindulatú szexizmus" (Fiske - Cuddy - Glick - Xu, 2002) jegyeit mutatja, ahol óvják és védelmezik a nőket, de csak addig, amíg azok elfogadják a hagyományos női szerepeket. Ezeket a véleményeket a háztartás és gyereknevelés terén a hagyományos munkamegosztáshoz, a női-férfi viszonyban pedig a női önkéntes alárendeléshez való ragaszkodás jellemzi, ami a karrierizmus (Collinson - Hearn, 1994) konstrukciójával is hasonlóságot mutató vélelmezés. Az otthontól különvált munkahelyre (Braudy, 2005) ugyan bejutottak a nők, de egyes férfi vezetőkben a róluk kialakult képek még mindig az otthonhoz és a anyaszerephez kötik őket.

\section{Hérák és Artemiszek}

Az utolsó csoport narratívái sem a meritokrácia, sem pedig a hatékonysági szempontok szerint nem támogatják a nők felsővezetői részvételét. E vélemények szerint a nők - az előzőkkel ellentétben - nem is alkalmasak a felsővezetői szerepek ellátására. E vélemények hangoztatói úgy vélik, hogy a nők csak végrehajtói vagy mechanikus rutinmunkákra alkalmasak, de nem képesek stratégiai, nagy felelősséggel járó komplex feladatok ellátására. Véleményeiket gyakran feleségeikkel kapcsolatos percepcióikra hivatkozva alakítják ki, amit kiterjesztenek az összes nőre. Így a nőkben elsősorban a másodhegedűs szerepet játszó feleséget vagy a vezetői képesség nélküli munkatársat látják. E nőalakok egyik metaforája az előzőekben már bemutatott Héra, aki itt nem a hiányzó, hanem a jelenlévő, a munkahelyen dolgozó nők férfivezetők általi percepciójának metaforája. Afrodité pedig a szerelem istennőjeként a nők párkapcsolati szerepének metaforája, ahol a nő célja a férfi elbüvölése.

A negatív véleményü csoportba tartozó narratívák a hatékonyság növelésének akadályának tekintik azt, ha nőket is bevonnak a felső vezetésbe. Ennek egyik indokát a családi munkamegosztással magyarázta az egyik interjúalany:

„Általában a normális pasiknak van anyukájuk meg feleségük. Kialakul a családi munkamegosztás. [...] A nö intézi, amit neki kell intézni, de azért a pasi [ott van] a nagy dolgokban, pénzben, szintetizálásban, a logisztikának az összeállitásában.”

Ez a kép vetül ki a vállalatra is, mondván, hogy a nők csak a végrehajtásban jók, de nincs elég képességük a komplex helyzetek megoldására.

Bár a modern vezetéstudomány a feladathoz való elköteleződést pozitív motivációs tényezőként kezeli, egy másik narratíva éppen ezzel ellentétes tartalmú. Eszerint az elköteleződés a vezetői alkalmatlanság egyik jele, amit egy régebben hallott mondás is bizonyít:

„, Igazából a nőket nem lenne szabad bírónak engedni csak ügyvédnek, mert valamelyik szereplövel általában a nö azonosul." 
Az elköteleződés problémát az autoriterizmus (Collinson - Hearn, 1994) kultúrájában okoz, ahol mindenkinek a fönök aktuális preferenciáihoz kell igazodnia. E narratíva az „ellenséges szexizmus” érveivel rokon.

Egy másik narratívából pedig az derült ki, hogy az, hogy a nőket nem hívják meg bizonyos szabadidős tevékenységekre a férfivezetők nem véletlen, és nem a tevékenység jellegéből adódik, hanem szándékos, mert a férfiak ,el akarják engedni magukat”:

„Közösen elmegyünk inni, meccsre. A pasik ki tudják beszélni a nőkkel kapcsolatos ügyeiket. Ez olyan, mint amikor a pasik rendszeresen eljártak vadászni [...] és a nök maradtak otthon az öregekkel és a gyerekekkel."

Aki pedig ebben nem vehet részt, szól egy hasonló narratíva, az kimarad fontos információkból, kapcsolatokból, és nem tudja ellátni feladatát és ezzel be is zárul az ördögi kör. Ezek a vélemények összhangban vannak a „öltözői kultúra” (Maddock - Parkin, 1993) metafora által jellemzett kapcsolati hálón alapuló maszkulin konstrukciókkal. A meritokrácia sérülésével jár, mert - amint a fenti példa is mutatja - a nőket kizárja a bizalmi körből, hátrányos helyzetbe hozza a kapcsolatok építése során, ami a felsővezetői kinevezési döntéseknél hátrányt jelent.

A cikk elején megfogalmazott előfeltevéseket szemügyre véve az alábbi megállapításokat tehetjük.

- Nem igazolódott az az előfeltevés, hogy a férfi döntéshozók nem szívesen vesznek részt a kutatásban. Valamennyi megkeresett interjúalany azonnal és szívesen vállalkozott az interjúra, bármilyen véleményt képviselt is a témával kapcsolatban. Bíztak abban is, hogy megállapodásunknak megfelelöen megörzöm névtelenségüket. Ez felveti a személyes bizalom fontosságát a hasonló kutatásokban.

- Várakozásaim a maszkulin narratívákkal kapcsolatban csak részben teljesültek. A végső kép sokszínübb lett, mint vártam. Ez a tény az alacsony várakozások miatt csak nagyon mérsékelten, de mégis némi optimizmusra ad okot.

- A most és itt kérdésre viszont sokféle válasz érkezett, melyeket négy metafora keretében összegeztem.

\section{Összegzés, korlátok és további kutatási irányok}

A cikkben bemutatott kutatás eredménye sokszínüséget mutat. A hatékonyság és a meritokrácia tengelyei mentén összesen négyféle narratívacsoport körvonalai rajzolódtak ki (lásd 3. és 4. ábra). Az elsőt az jellemzi, hogy bár Magyarországon a női részvétel a politikai életben nagyon alacsony, az üzleti világban a hatékonysági és meritokratikus megfontolások alapján e csoport férfivezetőiben már kialakult a női tehetségek kinevezésére való hajlandóság, majd pozitív tapasztalataik hatására a befogadó, elismerő és támogató viselkedés.

A másik három csoport esetében elmondható, hogy mind a magyar, mind pedig a hosszabb ideje itt dolgozó külföldi vezetők körében megfigyelhető a ,jószándékú” és egyes esetekben még az „ellenséges szexizmus” is. A ,jószándékú szexizmus", a tudattalan torzítások jelei még akkor is felfedezhetők, ha egy vezető külső nyomásra kinevez ugyan női vezetőket, de vezetési kultúrájában mégis paternalisztikusan, ,gentlemen's club” stílusban vezeti őket, vagy a karrierizmus jegyében, a nőket oda nem illö versenytársnak tekinti.

Ez a jelenség a párbeszéd, a meggyőzés és a jó tapasztalatok megosztásának fontosságára hívja fel a figyelmet. A célok internalizálására még a meritokráciát támogató belső szabályok és kvóták mellett is nagy szükség van, mert csak így valósulhat meg a vallott és követett értékek egysége. Ezen az úton kihívást jelent, hogy a negatív konstrukciók kialakulásáról, a háttérben zajló folyamatokról, a lényegi változások módjairól még nem rendelkezünk elegendő ismerettel. A folyamatok további, mélyebb feltárása nemcsak a döntések konstruálásának folyamata és a cégkultúrára gyakorolt hatásuk miatt fontosak, hanem azért is, mert a férfiak a közvélekedésre, a tágabb közösség valóságkonstrukciós folyamataira a nőknél nagyobb hatást tudnak kifejteni társadalmi szempontból nagyobb befolyásoló erejük miatt.

A meritokrácia érvényesülésének vizsgálata e cikkben azért a férfi és női érvényesülési lehetőségek, felsővezetői kinevezések példáján keresztül történt, mert az a jelenség megbízható statisztikai adatokkal jól megfigyelhető. Itt a kutatás korlátozó tényezőjét a háttérfolyamatok feltárására irányuló kvalitatív kutatás módszertanából adódó korlátozott elemszáma jelenti. Korábbi kutatások azonban azt is feltárták, hogy férficsoportok is képesek háttérbe szorítani közéjük nem tartozó férfiakat, és arról is rendelkezünk ismeretekkel, hogy egyes vezető pozícióba kerülő nők is ellenségesen viselkedhetnek versenytársnak tekintett tehetséges nőkkel szemben, megfosztva őket fontos lehetőségektől, és eltávolítják őket a döntéshozói körből. E jelenségek hazai vizsgálata további kutatási irányt jelent, mely kvantitatív adatok hiányában kvalitatív eszközökkel valósíthatók meg.

\section{Felhasznált irodalom}

Acemoglu, D. (2009): Introduction to Modern Economic Growth. Princeton: Princeton University Press Acker, S. (1995): Carry on Caring: The Work of Women Teachers. British Journal of Sociology of Education, vol. 16, p. 21-36. doi.org/10.1080/0142569950160102

Adler, N. - Izraeli, D. N. (eds.) (1988): Women in management worldwide. Armonk, N.Y. : M.E. Sharpe

Allen, T. D. - Eby, L. - Poteet, M. L. - Lentz, E. (2004): Career Benefits Associated With Mentoring for Proteges: A Meta-Analysis. Journal of Applied Psychology, March, p. 127-136 . DOI: 10.1037/0021-9010.89.1.127

Alvesson, M. - Billing, J. D. (1997): Understanding Gender and Organization. Thousand Oaks: Sage

Barnard, S. - Hassan, T. - Bagilhole, B. (2012): 'They are not girly girls': an exploration of quantitative and qualitative data on engineering an gender in higher education. European Journal of Engineering Education, vol. 37, iss. 2., p. 193-204.

Bendl, R. - Schmidt, A. (2010): From Glass Ceilings to Firewalls - Different Metaphors for Describing Discri- 
mination. Gender, Work and Organization, 17(5), p. 612-634.

Berger, A. N. - Schaeck, K. - Kick, T. (2014): Executive board composition and bank risk taking. Journal of Corporate Finance, Volume 28, Oct., p. 48-65. doi. org/10.1016/j.jcorpfin.2013.11.006

Blaikie, N. (2007): Approaches to social enquiry. Cambridge: Polity Press

Bolen, J. S. (2008): Bennünk élő istennők. Budapest: Studium Effektíve Kiadó

Braudy, L. (2005): From Chivalry to Terrorism: War and the Changing Nature of Masculinity. New York: Vintage Books

Broadbridge, A. - Simpson, R. (2011): 25 Years On: Reflecting on the Past and Looking to the Future in Gender and Management Research. British Journal of Management, vol. 22, iss. 3., p. 470-483. doi. org/10.1111/j.1467-8551.2011.00758.x

Bruckmüller, S. - Branscombe, N. R. (2010): The glass cliff: When and why women are selected as leaders in crisis contexts. British Journal of Social Psychology, 49, p. 433-451.

Carrigan, T. - Connell, B. - Lee, J. (1985): Toward a new sociology of masculinity. Theory and Society, Vol. 14, No. 5, p. 551-604.

Carter, N. M. - Silva, C. (2010): Women in Management: Delusions of Progress. Harvard Business Review, March

Collinson, D. - Hearn, J. (1994): Naming men as men: Implications for work, organization and management. Gender, Work and Organization, vol. 1, iss. 1, p. 2-22.

Danowitz, M. A. - Hanappi-Egger, E. - Mensi-Klarbach, H. (2012): Diversity as Strategy. In: Danowitz, M. A. Hanappi-Egger, E. - Mensi-Klarbach, H. (eds.): Diversity in Organizations: Concepts and Practices. London: Palgrave Macmillan, p. 137-158.

Denzin, N. K. - Lincoln, Y. S. (2005): The SAGE Handbook of Qualitative Research. Thousand Oaks, London, New Delhi: SAGE

Dunavölgyi, M. (2016): Women and Men in Senior Management: Key Recurring Themes and Questions. Vezetéstudomány, vol, 47, iss. 5., p. 64-82.

Eagly, A. H. - Carli, L. L. (2007): Women and the Labyrinth of Leadership. Harvard Business Review, Sept., p. 63-71.

Eckes, T. (2002): Paternalistic and Envious Gender Stereotypes: Testing Predictions From the Stereotype Content Model. Sex Roles, 47(3-4), p. 99-114. http://dx.doi. org/10.1023/A:1021020920715

EIGE (2017): EIGE gender-statistics. Forrás: EIGE: http:// eige.europa.eu/gender-statistics/dgs/indicator/wmidm_bus_bus_wmid_comp_compex/bar/year:2017B1/

Ellis, C. -Adams, T. E. - Bochner, A. P. (2010): Autoethnography: An Overview . Forum Qualitative Sozialforschung / Forum: Qualitative Social Research, 12(1), Art. 10, http://nbn-resolving.de/urn:nbn:de:0114fqs1101108. Forum Qualitative Sozialforschung / Forum: Qualitative Social Research.
European Comission (2016a): Forrás: European Comission Strategic Engagement for Gender Equality: http:// ec.europa.eu/justice/gender-equality/document/files/ strategic_engagement_en.pdf

European Comission (2016b): Forrás: Gender Balance on Corporate Boards: http://ec.europa.eu/justice/genderequality/files/gender_balance_decision_making/1607_ factsheet_final_wob_data_en.pdf

Eurostat (2017. 06 01): Forrás: Statistics Explained: http:// ec.europa.eu/eurostat/statisticsexplained

Featherstone, B. (2004): Fathers Matter: A Research Review. Children and Society, Volume18, Issue 4, p. 312319. https://doi.org/10.1002/chi.842

Fiske, S. T. - Cuddy, A. J. - Glick, P. - Xu, J. (2002): A Model of (Often Mixed) Stereotype Content: Competence and Warmth. Journal of Personality and Social Psychology, Vol. 82, No. 6, p. 878-902. DOI: 10.1037//00223514.82.6.878

Gadamer, H. G. (2003): Igazság és módszer: Egy filozófiai hermeneutika vázlata. Budapest: Osiris

Gelei, A. (2006): A szervezet interpretatív megközelítése. Vezetéstudomány, vol. 38 (1. ksz), p. 79-97.

Gherardi, S. (1996): Gendered Organizational Cultures: Narratives of Woman Travellers in a Male World. Gender, Work and Organization, vol. 3, number 4, p. 187201.

Gill, J. - Sharp, R. - Mills, J. - Franzway, S. (2008): I still wanna be an engineer! Women, education and the engineering profession. European Journal of Engineering Education, Volume 33, Issue 4, p. 391-402.

Glense, C. - Peshkin, A. (1992): Becoming qualitative researchers: An introduction. New York: Longman

Gould, S. J. (1995): Researcher Introspection as a Method in Consumer Research: Applications, Issues, and Implications. Journal of Consumer Research, Vol. 21, No. 4, p. 719-722.

Graves, R. (1981): Görög mítoszok. Budapest: Európa

Hanappi-Egger, E. (2011): The triple M of organizations: Man, Management and Myth. Heidelberg: Springer

Haslam, S. A. - Ryan, M. K. (2008): The road to the glass cliff: Differences in the perceived suitability of men and women for leadership positions in succeeding and failing organizations. Leadership Quarterly, October, p. 530-546. https://doi.org/10.1016/j.leaqua.2008.07.011

Heilman, M. E. (2001): Descpiption and prescription: How gender stereotypes prevent women's ascent up the organizational ladder. Journal of Social Issues, Volume57, Issue 4, p. 657-674. https://doi.org/10.1111/00224537.00234

Horváth, D. - Mitev, A. (2015): Alternatív kvalitatív kutatási kézikönyv. Budapest: Aliena

Howe, N. - Strauss, W. (1992): Generations. London: Harper Collins

Janesick, V. J. (2003): The Choreography of Qualitative Research Design. In: Denzin, N. K. - Lincoln, Y. S. (eds.) (2003): Strategies of Qualitative Research Inquiry. Thousand Oaks: Sage, p. 35-55.

Kanter, $R$. (1977b): Some effects of proportions on group life: Skewed sex ratios and responses to token women. 
The American Journal of Sociology, Vol. 82, No. 5, p. 965-990.

Kanter, R. M. (1977a): Men and women of the organization. New York: Basic Books

Katila, S. - Meriläinen, S. (1999): A Serious Researcher or Just Another Nice Girl?: Doing Gender in a MaleDominated Scientific Community. Gender, Work and Organization, 6(3), p. 163-173.

Kluegel, J. - Csepeli, G. - Kolossy, T. - Örkény, A. - Neményi, M. (1995): Accounting for the Rich and the Poor: Existential Justice in Comparative Perspective. In: Kluegel, J. R. -Mason, D. S. - Wegener, B. (eds.): Social Justice and Political Change. New York: Aldine de Gruyter, p. 179-201.

Kornau, A. - Festing, M. (2013): The impact of male-oriented organisational cultures on the career advancement of female managers: A review and a framework for future research. 13.

Kovács, M. - Szabó, M. (2017): Társadalmi nem és szexizmusok: a nemi hierarchiát igazoló nézetrendszerek elfogadása és elutasítása. In: Kovács, M. (szerk.): Társadalmi nemek. Budapest: ELTE Ötvös Kiadó, p. 39-57.

KSH (2016): A Magyarországon müködő külföldi irányítású leányvállalatok tevékenysége a 2015. évi végleges és a 2016. évi előzetes adatok alapján. Budapest: KSH

Kürtösi, Z. (2007): Az informális kapcsolathálók müködéséek nemi különbségei egy szervezetben. Vezetéstudomány, jan., p. 18-29.

Kvale, S. (1996): InterViews: An Introduction to Qualitative Research. Thousand Oaks: Sage

Kvale, S. (2005): Az interjú. Budapest: Jószöveg Mühely

Lewis, P. - Simpson, R. (2010): Meritocracy, difference and choice: women's experiences of advantage and disadvantage at work. Gender in Management: An International Journal, Vol. 25 Issue: 3, p.165-169, https://doi. org/10.1108/17542411011036374

Liff, S. - Ward, K. (2001): Distorted views through the glass ceiling: the construction of women's understandings of promotion and senior management positions. Gender, Work - Organization, vol. 8, number 1, p. 1936.

Maddock, S. - Parkin, D. (1993): Gender Cultures: Women's Choices and Strategies at Work. Women in Management Review, Dec., p. 3-9.

Martin, P. Y. (1993): Feminist Practice in Organizations. In: Fagenson, E. A. (ed.): Women in Management. Thousan Oaks: SAGE, p. 274-296.

Mason, J. (2005): Kvalitatív kutatás. Budapest: Jószöveg Mühely Kiadó

Mavin, S. (2008): Queen Bees, Wannabees and Afraid to Bees: no more 'best enemies' for women in management? British Journal of Management, Volume19, Issues1, p. 575-584. https://doi.org/10.1111/j.14678551.2008.00573.x

Maxwell, J. A. (2013): Qualitative Research Design. Thousand Oaks: Sage

Meyerson, D. - Fletcher, J. (2000): A modest manifesto for shattering the glass ceiling. Harvard Business Review, Jan-Febr., p.126-136.
Miller, G. (2002): The frontier, entrepreneurialism, and engineers: women coping with a web of masculinities in an organizational culture. Culture and Organization, Volume 8, Issue 2, p. 145-160. https://doi. org/10.1080/14759550212836

Mills, C. W. (1959): On intellectual craftsmenship. In: Mills, C. V. (ed.): The sociological imagination. Oxford: Oxford University Press, p. 195-212.

Nagy, B. (2001): Női menedzserek. Budapest: Aula

Nagy, B. (2007): A társadalmi nem szerepe a vezetésben Magyarországon (The role of gender in management in Hungary). Budapest: Aula Kiadó

Nagy, B. - Primecz, H. (2010): Nők és férfiak a szervezetben - kísérlet a mítoszok eloszlatására. Vezetéstudomány, jan., p. 2-17.

Okin, S. M. (1979): Women in Western Political Thought. Princeton: Princeton University Press

Örkény, A. - Székelyi, M. (2000): Views on Social Inequality and the Role of the State: Posttransformation Trends in Eastern and Central Europe. Social Justice Research, Volume 13, Issue 2, p. 199-218.

Pass, C. (2004): Corporate governance and the role of nonexecutive directors in large UK companies: an empirical study. Corporate Governance: The international journal of business in society, Vol. 4 Issue: 2, p. 52-63.

Pongrácz, T. (2001): A család és a munka szerepe a nők életében. Budapet: Tárki

Powell, G. (2012): Six ways of seeing the elephant: the intersection of sex, gender, and leadership. Gender in Management: An International Journal, Vol. 27 Issue: 2, p. 119-141.

Putnam, H. (1990): Realism with a human face. Cambridge MA: Harvard University Press

Reif, W. E. e. a. (1975): Exploding some myths about women managers. California Management Review, July, p. $72-79$.

Rorty, R. (ed.) (1992): The Linguistic Turn. Chicago: University of Chicago Press

Schein, E. H. (2004): Organizational Culture and Leadership. San Francisco, CA: Jossey-Bass

Simpson, R. - Ross-Smith, A. - Lewis, P. (2008): Merit, special contribution and choice. Gender in Management: An International Journal, Vol. 25 Issue: 3, p. 198-207. https://doi.org/10.1108/17542411011036400

Sinclair, A. (2005): Doing Leadership Differently. Melbourne: Melbourne University Press

Strauss, A. - Corbin, J. M. (1990): Basics of qualitative research: Grounded theory procedures and techniques. Newbury: Sage

Suddaby, R. (2006): From the editors: What grounded theory is not. Academy of Management Journal, Vol. 49, No. 4, p. 633-642.

Szekeres, V. - Takács, E. - Vicsek, L. (2013): Lányok útja a müszaki diplomáig. In: Szekeres, V. (szerk.): "Ti ezt tényleg komolyan gondoltátok?" Nők és a müszaki felsőoktatás. Budapest: Óbudai Egyetem, p. 15-213.

Terjesen, S. - Singh, V. (2008): Female presence on corporate boards: a multi-country study of environmental context. Journal of Business Ethics, Nov, p. 55-63. 
Tóth, H. (2005): Gendered dilemmas of the work-life balance in Hungary. Women in Management Review, July, p. 361-375.

Trencsényi-Waldapfel, I. (1983): Mitológia. Budapest: Gondolat

Trencsényi-Waldapfel, I. (1990): Görög regék. Bukarest: Kriterion

Van Oostende, M. - Chiercia, G. - Martens, K. (2012): Women matter: Making the breakthrough. Boston: McKinsey Company

Wajcman, J. (1998): It's Hard to be Soft: Is Management Style Gendered? In: Wajcman, J. (1998): Managing Like a Man: Women and Men in Corporate Management. Chichester: Wiley, p. 333-349.
Wajcman, J. (1998): Managing like a Man. Chichester: Wiley

White, R. P. - Morrison, A. M. - Van Velsor, E. (1987): Breaking the Glass Ceiling: Can Women Reach the Top of America's Largest Corporations? New York: Basic Books

Williams, C. L. (1992): The Glass Escalator: Hidden Advantages for Men in the "Female" Professions. Social Problems, Aug, p. 253-267.

Young, M. (1958): The Rise of the Meritocracy. London: Transaction Publishers

Zahidi, S. - Ibarra, H. (2010): The corporate gender gap report 2010. Geneva: World Economic Forum. 